\title{
Chapter 5 \\ Diaspora Policies, Consular Services and Social Protection for Chinese Citizens Abroad
}

\author{
Elena Barabantseva and Tao Wang
}

\subsection{Introduction}

This chapter offers an overview of the recent policy developments initiated by the government of the People's Republic of China (PRC or China hereafter) in the area of social protection of its citizens living abroad. Chinese leaders regularly emphasise the importance of China's sizeable overseas population towards achieving China's goals of socio-economic development, technological advancements, and territorial sovereignty. The 2018 State Council Report on the Protection of Overseas Chinese Rights and Interests stresses that 'the overseas Chinese have an irreplaceable important role in realizing the Chinese dream'. ${ }^{1}$ Since the late nineteenth century, China's imperial officials and reformers - and latterly, its revolutionaries - have recognised the socio-economic value and political potential of overseas Chinese for their homeland. For example, Sun Yatsen, the leader of the 1911 Revolution, widely viewed as the father of modern China, famously called overseas Chinese 'the Mother of the revolution'.

Recent official estimates put the number of overseas Chinese nationals at six million, ${ }^{2}$ with the following five countries hosting the largest numbers of Chinaborn population: the United States (US-2,335,000 residents born in China according

\footnotetext{
${ }^{1}$ Standing Committee of the 13th National People's Congress. (2018). 国务院关于华侨权益保护 工作情况的报告 [Report of the state council of protection of overseas Chinese rights and interests"]. http://www.npc.gov.cn/npc/xinwen/2018-04/25/content_2053574.htm. Accessed 4 March 2019.

${ }^{2}$ See footnote 1 .
}

E. Barabantseva $(\bowtie) \cdot$ T. Wang

University of Manchester, Manchester, UK

e-mail: E.V.Barabantseva@manchester.ac.uk 
to the 2016 data of the US Census Bureau), ${ }^{3}$ Canada (649,260 according to 2016 Census), ${ }^{4}$ Japan $\left(878,000\right.$ by media estimates in 2017), ${ }^{5}$ Australia $(318,969$ according to the 2011 Census), ${ }^{6}$ and the United Kingdom (UK- 182,628 residents born in China according to the 2015 Census). ${ }^{7}$ Characterised as a 'high-end' wave of Chinese migration, it was made possible by the government relaxation of institutional and legal barriers for leaving China that opened up opportunities for highlyskilled and well-off people to seek new educational, investment, and career prospects abroad (Xiang 2016). The majority of these 'new migrants' left China after the beginning of reforms in the late 1970s and are now the main target of the state diaspora policies.

“Overseas Chinese affairs work” (qiaowu gongzuo 侨务工作) is the traditional term that the PRC uses to refer to its policies towards Chinese people abroad and it has not changed since the Mao era (1949-1975). The range of state activities, however, has in recent decades expanded in multiple directions, including flexible exit and entry arrangements, incentives for investments, favourable social protection for overseas Chinese returnees, soft power projection, and pro-China propaganda. ${ }^{8}$ Since the late 1970s, when China introduced pro-market reforms and became single-mindedly focused on economic growth, the core of "Overseas Chinese affairs work" has been economic policies. Policymakers across the country try every means to entice Chinese diaspora to invest in China, using tax exemption, cheap land, lowinterest loans and even free cash.

As China's economic engine has begun to shift from manufacturing to technology, recruiting overseas Chinese talent has become a new mission. Scientists, professors, and bankers of Chinese descent have frequently been recruited back to

\footnotetext{
${ }^{3}$ Zong, Jie and Batalova, Jeanne. (2017). Chinese Immigrants in the United States. Migration Policy Institute. https://www.migrationpolicy.org/article/chinese-immigrants-united-states. Accessed 12 June 2019.

${ }^{4}$ Statistics Canada (2019). Immigration and Ethnocultural Diversity Highlight Tables - Immigrant population by place of birth, period of immigration, 2016 counts, both sexes, age (total), Canada, 2016 Census - 25\% sample data, https://www12.statcan.gc.ca/census-recensement/2016/dp-pd/ hlt-fst $/ \mathrm{imm} /$ Table.cfm?Lang=E\&T=21\&Geo=01\&SO=4D. Accessed 12 June 2019.

${ }^{5}$ Schreiber, M. (2018). Media stews over growing Chinese numbers in Japan. The Japan Times. https://www.japantimes.co.jp/news/2018/07/14/national/media-national/media-stews-growingchinese-numbers-japan/\#.XP-artNKjdc. Accessed 12 June 2019.

${ }^{6}$ Department of Social Services of the Australian Government (2014). The China-Born Community. https://www.dss.gov.au/our-responsibilities/settlement-services/programs-policy/a-multiculturalaustralia/progra ms-and-publications/community-information-summaries/the-china-born-community. Accessed 12 June 2019.

${ }^{7}$ Office for National Statistics (2018). Table 1.3: Overseas-born population in the United Kingdom, excluding some residents in communal establishments, by sex, by country of birth, January 2017 to December 2017, https://www.ons.gov.uk/peoplepopulationandcommunity/populationandmigration/internationalmigration/methodologies/populationbycountryofbirthandnationalityqmi. Accessed 12 June 2019.

${ }^{8}$ Overseas Chinese Affairs Cadres' School of the Overseas Chinese Affairs Office of the State Council (2015). Q\&A on Policies and Regulations about Overseas Chinese Affairs. Beijing: Shijie Zhishi Press.
} 
China, often with incredibly generous offers. By contrast, when it comes to social welfare protection of Chinese nationals living abroad, the resources provided by the government are stunningly sparse. In this chapter, we show how China's welfare policies towards its nationals abroad varies from one field to another. We find that under almost any circumstances including unemployment, medical emergency and economic hardship, Chinese consulates do not provide financial assistance to citizens abroad. Social protection is limited to providing information, visa arrangements, contacting family members in China and other logistical support. Outside of crisis situations affecting a large number of Chinese workers overseas, the areas of social welfare and protection of nationals abroad remain largely outside of the state's concern.

\subsection{Diaspora Characteristics and Home Country Engagement}

Since Xi Jinping's ascent to power in 2012, overseas Chinese have been given an increasingly important role in China's soft power strategy abroad including cultural and educational exchanges, internationalisation of Chinese media, and transmission of Chinese culture and language (Ding 2015: 235). Furthermore, with the growing expansion of China's "Go Global" policies and their most recent reincarnation of the "One Belt, One Road" initiative introduced by Xi Jinping in 2013, the imperative nature of overseas Chinese citizens' protection has increased. With the expansion of Chinese development and infrastructure projects abroad, the exposure to social unrest, violence and political volatility among Chinese nationals working on overseas projects has increased. Since the attacks on Chinese workers in Afghanistan and Pakistan in 2004, and a major rescue operation in East Timor in 2006, overseas citizens' protection has become a 'new diplomatic imperative' (Zerba 2014: 1094). In 2011, China carried out the first large-scale evacuation operation of 35,000 Chinese nationals from the civil war in Libya (Zerba 2014). The significance of such operations for China's global image-making is reiterated by the fact that they have informed the storylines of state-funded nationalistic blockbusters such as Wolf Warrior 2 and Operation Red Sea (Connolly 2019). This latest phase in the evolution of China's policies towards its nationals abroad builds on the long history of diaspora engagement. The surprisingly high number of Chinese residing in Libya is simply the tip of the iceberg of China's diaspora across the world. Indeed, the bond between China and its diaspora communities has never been weak. 


\subsubsection{The Chinese Diaspora and its Relations with the Homeland}

The Chinese diaspora has historically played a central role in the Chinese national projects of modernisation and development. Since the late nineteenth century, when a sizeable number of Chinese migrants started settling in Asia, the Americas, and Europe, Chinese rulers recognised the potential economic and political role that these communities could play in realising China's transformational objectives. In recognition of the hardship and plight of Chinese labourers overseas, the first nationality law of 1909 introduced by the Qing Imperial Court adopted the jus sanguinis principle and offered them consular protection. This law was predicated on the idea that all people of Chinese descent are members of the Chinese nation and should be protected by its government. During the late 19th - early twentieth century's revolutionary campaign led by Sun Yat-sen against the dynastic rule of the Qing and foreign domination, overseas Chinese communities in Southeast Asia and the US were central to his efforts to raise funds for the national survival project. Although the dual citizenship principle was repudiated in favour of the single citizenship by the PRC government in 1956, state policies towards overseas communities have developed into an area of important ideological and economic policy activities. In the pre-reform period, overseas Chinese communities were part of the United Front campaign which was dedicated to the revolutionary struggle, while in the post-reform period, modernisation became its foremost goal. Historically, the main objective of China's engagement with its overseas populations has been improving China's “international image, promoting China's domestic and foreign advancement, and raising the status of the OC in their places of residence" (To 2014).

Most official pronouncements about state policies towards overseas Chinese begin with an estimation of the number of Chinese living abroad. In the 1990s, Chinese policymakers gave the number of 30 million overseas Chinese worldwide, which ambiguously referred to overseas Chinese nationals (huaqiao) and people of Chinese descent (huaren) (Zhao 1994: 8). By 2017, according to official publications, this figure had doubled to 60 million (Wang and Kang 2017). Developing a comprehensive and complex apparatus to include overseas Chinese into China's domestic reforms and overseas strategies has become an essential part of China's post-1978 development model. Central to this project are China's goals of economic and technological development, revival of national strength, and growing global influence. The protection of rights and interests belonging to overseas Chinese is enshrined in the Constitution of the PRC, with Article 50 specifically dedicated to the subjects of overseas Chinese and returned overseas Chinese. It states: "The People's Republic of China protects the legitimate rights and interests of Chinese nationals residing abroad and protects the lawful rights and interests of returned 
overseas Chinese and of the family members of Chinese nationals residing abroad". This area of state activities has been in constant fluctuation.

\subsubsection{Diaspora Infrastructure}

The institutional network involved in delivering China's diaspora policy is vast, ranging from government agencies, party apparatus, and non-governmental associations to consulates, embassies and representative organizations across the globe. It is not only enormous in size, but also complex. Owing to a unique party-state system, there is a fine line between state and party, between legislative and executive branches, and between governmental and non-governmental agencies.

In terms of international infrastructure, the PRC has an extensive consular network in 178 countries across the world, in addition to mobile consular services in areas where there is no physical consulate in operation. In each consulate, there is usually a department named Overseas Chinese Team tasked to deal with diaspora issues. This team consists of career diplomats appointed by the Ministry of Foreign Affairs. It is the first official contact point for Chinese abroad who need consular services and social protection. Beyond the bricks and mortar of Chinese consulates, semi-governmental agencies are set up all over the globe. For example, in 2004, the government launched Confucius Institutes around the world with the mission to promote Chinese culture and language. Although primarily aimed at foreign populations, Confucius Institutes work actively with Chinese consulates. In addition, the Chinese Students and Scholars Association (CSSA), operating across university campuses outside of China, also plays a role in the diaspora infrastructure. By holding cultural events such as annual Chinese New Year galas and food festivals, the CSSA fosters new links connecting Chinese diaspora communities with overseas Chinese students. Since 2014, a network of grassroots Overseas Chinese Mutual Aid Centres staffed by volunteers and receiving support from and acknowledgment by the Chinese central government have started appearing around the world.

These institutions abroad, however, should be considered as an extension and the tip of the iceberg of the massive superstructure within China. Domestically, at the centre of this superstructure are five interrelated governmental and party institutions, also known as five qiao (wu qiao 五侨) (Liu and van Dongen 2016). “The big five" are: the Overseas Chinese Affairs Office of the State Council, the Overseas Chinese Affairs Committee of the National People's Congress (NPC), the Hong Kong, Macau, Taiwan Compatriots and Overseas Chinese Affairs Committee of the National Committee of the Chinese People's Political Consultative Conference (CPPCC), the All-China Federation of Returned Overseas Chinese, and the China Zhi Gong Party.

\footnotetext{
${ }^{9}$ The National People's Congress (2004). Constitution of the People's Republic of China. http:// www.npc.gov.cn/englishnpc/Constitution/node_2825.htm. Accessed 4 March 2019.
} 
Overseas Chinese Affairs Office (OCAO) of the State Council stands at the core of China's diaspora infrastructure. Once a ministry, in 2018 it was merged into a party apparatus of the Communist Party of China (CPC), namely, the United Front Work Department of Chinese Communist Party Central Committee. ${ }^{10}$ The OCAO is an overarching unit in charge of proposing laws and regulations regarding overseas Chinese, coordinating, supervising and implementing China's diaspora policies throughout all levels of the government. It also formulates and promotes China's soft power agenda abroad and provides guidance for overseas Chinese organizations.

The National People's Congress is the PRC's legislative branch. The Overseas Chinese Affairs Committee is thus a legislative sub-organization with a specific duty in the area of diaspora issues. Currently consisting of 20 members, the Committee proposes and evaluates laws related to overseas Chinese; monitors executive branch performance and reports any inconsistencies when the executive branch does not follow the Constitution and national laws; undertakes hearings; and gathers information and investigates issues relevant to diaspora. ${ }^{11}$

The National Committee of the Chinese People's Political Consultative Conference (CPPCC), in practice, is the country's top political advisory body, a restricted version of the United Kingdom's House of Lords. In China's party-state system, the main mission of the CPPCC is to draw support for the CPC among nonparty members including Chinese nationals residing abroad. At the CPPCC, the Hong Kong, Macau, Taiwan Compatriots and Overseas Chinese Affairs Committee handles issues related to Hong Kong, Macau, Taiwan and overseas Chinese.

The All-China Federation of Returned Overseas Chinese is a "non-governmental organization" under the leadership of the CPC. Although its main task is focused on returned overseas Chinese, the organization is also in charge of addressing the needs of nationals residing abroad. Unlike governmental organizations in China, the Federation has its emphasis on public diplomacy. This is reflected in its own slogan: "consolidating old friendship and broadening new friendship."

The China Zhi Gong Party is one of the eight minor parties that are legally permitted but are subordinate to the Communist Party of China. The Zhi Gong Party largely consists of returned overseas Chinese, their relatives, and those who have overseas connections. Its core mission is to maintain ties with overseas Chinese communities, using its intermediate role to promote Chinese culture and language, and most importantly, developing pro-China patriotism among Chinese nationals residing abroad.

Each of "The Big Five" is a national institution which maintains a top-down hierarchy ranging from national, provincial to local offices. Besides "The Big Five",

\footnotetext{
${ }^{10}$ Chinese Communist Party Central Committee (2018). 深化党和国家机构改革方案 [The plan for deepening the reform of party and state institutions]. http://www.gov.cn/zhengce/2018-03/21/ content_5276191.htm\#1. Accessed 18 October 2018.

${ }^{11}$ The National People's Congress (1982). 中华人民共和国全国人民代表大会组织法 [Organic law of the National People's Congress of the People's Republic of China]. http://www.npc.gov.cn/ wxzl/wxzl/2000-12/06/content_4425.htm. Accessed 30 October 2018.
} 
many semi-official organizations such as the China Overseas Exchange Association serve as peripheral institutions of China's diaspora infrastructure. In addition, scholars estimate that several tens of thousands of grassroots overseas Chinese associations organized on the principle of kinship, place of birth, educational and professional affiliation and business networking are active worldwide (Liu and van Dongen 2016: 817).

\subsubsection{Key Engagement Policies}

The Chinese state's engagement with its nationals abroad places an overwhelming emphasis on encouraging investment and return of overseas Chinese talent back to China.

In China, foreigners' investment in the private sector enjoys a privileged status with substantial benefits, as the government is particularly interested in attracting foreign direct investment. Interestingly, investment by Chinese nationals residing abroad is treated as foreign direct investment. Furthermore, the equipment, vehicles and consumer goods that overseas Chinese import are exempted from import duty and commercial tax. In instances where overseas Chinese run companies that produce goods for export, the imported raw materials, components, equipment, and fuel are exempted from import duty and commercial tax. The final products for export are also exempted from export duty. ${ }^{12}$

In addition, the OCAO, in coordination with local governments, brought about a variety of policies to promote overseas Chinese business start-ups. For example, "Dream Incubators of Overseas Chinese" is a programme which aims to help overseas Chinese to develop new companies in China. Run by local governments, the incubators offer office space, low interest loans, government subsidies, and tax deduction among other incentives.

Investment in real estate in China is not particularly encouraged, given the saturated housing market. Chinese nationals residing abroad are allowed to purchase only one residential property for personal use. Although it appears to be a restriction, this policy is actually in favour of overseas Chinese when it comes to metropolitan cities. In Beijing, for example, the government has placed a cap on who is eligible to buy residential properties in order to control skyrocketing housing prices. Only those who are registered in Beijing's household system or have worked in Beijing for more than five years are permitted to buy. The Chinese citizens residing abroad, however, are required to revoke their household certificate before leaving the country. Thus, the special housing policy allows them to purchase one property

\footnotetext{
${ }^{12}$ The State Council (1990). 国务院关于鼓励华侨和香港澳门同胞投资的规定 [Regulations on encouragement of investments from overseas Chinese and Hong Kong and Macao compatriots]. http://www.mofcom.gov.cn/aarticle/b/f/200207/20020700031072.html. Accessed 19 October 2018.
} 
in a highly restricted market, regardless of their household certificate or working years. ${ }^{13}$

Not only overseas Chinese investment, but also overseas Chinese professionals are actively encouraged to return to China. Mainly targeting overseas Chinese, the government initiated the "Thousand Talents Plan" in 2008. ${ }^{14}$ This policy aims to bring about 2000 "top international talents" within five to 10 years to China, including scientists, researchers, entrepreneurs, and bankers. The recruited overseas Chinese usually hold full professorships in elite universities in the West, or management positions in multinational companies or international banks. The benefits that come with the plan are enormously attractive, even in comparison to similar positions worldwide. It is common for these scientists to be awarded research grants in excess of $\$ 1.5$ million, annual salaries of $\$ 150,000$, in addition to generous bonuses and housing allowance. ${ }^{15}$ Indeed, some universities even advertise positions offering research grants of up to $\$ 15$ million. ${ }^{16}$

Young overseas Chinese talent is also a target of overseas Chinese policies. When applying for Chinese universities, overseas Chinese high school students receive bonus points for the National College Entrance Exam (gaokao 高考). Once admitted, there are scholarships exclusively aimed at this group of overseas Chinese. The scholarships start at $4000 \mathrm{RMB}(\$ 600)$ on an annual basis and can be as high as 30,000 RMB (\$4500) per year. Each year, the government offers scholarships to thousands of students from overseas Chinese families.

Compared to their considerable efforts to attract investment and talent, consular services and social protection provided by the Chinese government to overseas Chinese are a recent development and remain limited. Information outlets including the “Consular Voice" (ling shi zhi shen 领事之声) on social media, an emergency hotline, and the “Ministry of Foreign Affairs 12308" (wai jiao bu 外交部12,308) smartphone application were set up to announce security warnings and important information concerning overseas Chinese. A gradual improvement in the area of “overseas citizen protection” (haiwai gongmin baohu 海外公民保护) has been developed in response to the mounting pressure to protect the growing number of Chinese nationals working on China's overseas infrastructure projects. The

\footnotetext{
${ }^{13}$ Chinaqw (2016). 华侨、华人如何在中国买房?需要注意这些程序 [How should overseas Chinese buy properties in China? Note this procedure]. http://www.chinaqw.com/ sqfg/2016/07-08/94588.shtml. Accessed 4 March 2019.

${ }^{14}$ Chinese Communist Party Central Committee (2008). 中央人才工作协调小组关于实施海外 高层次人才引进计划的意见 (千人计划) [Opinion by the central committee of CPC human resources coordinating team about the plan of recruiting leading international talents, also known as the thousand talents plan]. http://cpc.people.com.cn/GB/244800/244856/18246001.html. Accessed 3 November 2018.

${ }^{15}$ Harbin Institute of Technology (2015). 哈尔滨工业大学诚聘 ‘千人计划” 人选 [Harbin Institute of Technology to recruit candidates of the Thousand Talents Plan]. http://www.hit.edu. cn/282/list.htm. Accessed 4 March 2019.

${ }^{16}$ Western Returned Scholars Association (2018). 2018年千人计划即将启动 补贴最高450万 [2018 Thousand Talents Plan to start, subsidy up to 4.5 million]. http://www.wrsa.net/content_40351214.htm. Accessed 4 March 2019.
} 
Department of Consular Affairs of the Ministry of Foreign Affairs set up a division for consular protection in May 2006 with its subsequent upgrade in 2007 to the Centre for Consular Assistance and Protection (Zerba 2014). Although in recent years China has expanded the network of its consular support, improved emergency response and protection mechanisms of its citizens abroad, they remain limited outside of large-scale emergencies such as the Libya operation. By and large, Chinese consulates have a laissez-faire policy toward the social welfare of its nationals abroad. They do not, for example, offer any type of financial help such as subsidising medical costs, flights or hotels under any circumstances.

\subsection{Diaspora Policies and Social Protection in the PRC}

The engagement of the PRC's consular network, diaspora institutions and ministries in the area of social protection of Chinese nationals abroad is restricted. According to the Report of the State Council on the Protection of Overseas Chinese Rights and Interests that was adopted at the second meeting of the Standing Committee of the 13th National People's Congress in April 2018, "the rights and interests of overseas Chinese" are protected by law. ${ }^{17}$ The report provides an overview of the government's activities in the following three areas of overseas Chinese affairs: legal protection of the rights and interests of overseas Chinese; expansion of the mechanism to implement overseas Chinese policies; and propaganda among the overseas Chinese communities. In the area of social protection regarding the interests and rights of overseas Chinese, the report emphasises the right of the overseas Chinese to return to China in accordance with the "Regulations on the Procedures for the Return of Chinese to Settlement". ${ }^{18}$

Chinese schools abroad have traditionally constituted one of the central pillars (along with Chinese media and associations) of China's diaspora policies and have been a major source for identity orientation providing linguistic and cultural socialisation for new generations of overseas Chinese. They promote new kinds of global Chinese identities while maintaining strong cultural ties to their diasporic home (Ding 2015; Pieke 2012). By the 2010s, over 1000 supplementary Chinese language schools operated around the globe. In the United States alone, the Chinese School Association had 433 member schools listed on its website in $2019 .{ }^{19}$ The right to

\footnotetext{
${ }^{17}$ Standing Committee of the 13th National People's Congress (2018). 国务院关于华侨权益保护 工作情况的报告 [Report of the state council of protection of overseas Chinese rights and interests"]. http://www.npc.gov.cn/npc/xinwen/2018-04/25/content_2053574.htm. Accessed 4 March 2019.

${ }^{18}$ China Overseas Network (2017). 华侨回国定居应如何办理手续?[How should overseas Chinese return to China to settle down]. http://www.gqb.gov.cn/news/2017/0207/41734.shtml. Accessed 10 November 2018.

${ }^{19}$ Chinese School Association in the United States (2019) 全美中文学校协会简介 [About the Chinese School Association in the United States]. http://csaus.org/FHFRONT/csaus/about.jsp. Accessed 19 March 2019.
} 
education for the children of overseas Chinese is guaranteed in the PRC with two institutions of higher education, Jinan and Huaqiao Universities, recruiting returned overseas Chinese students.

The protection of social insurance rights and interests of overseas Chinese is administered by the Ministry of Human Resources and Social Security ${ }^{20}$ in accordance with the Law on Social Insurance. ${ }^{21}$ The PRC grants more social rights and economic opportunities to overseas Chinese returnees in China rather than to the Chinese communities abroad. The Guidance on China's Consular Protection and Assistance (2018) is the latest document outlining government policies and services for nationals abroad. ${ }^{22}$ It details the services that Chinese consular offices provide, in particular available sources of information and links to current government policies. The consular activities are limited to the traditional domains of consular protection, including provision of notarizations, certifications, and other document-related services. In case of health emergencies, the consulate can provide assistance with accessing health and legal aid, and repatriation in case of death, yet the cost of these services is covered by the person concerned or their family in China. As our survey of the government activities in the area of social protection of overseas Chinese shows, outside of large-scale operations, like the Libya crisis that affected a substantial number of Chinese nationals and cost the government 1 billion RMB, government agencies limit their protection of citizens abroad to the area of information rather than service provision.

\subsubsection{Unemployment}

In the area of unemployment, Chinese state institutions offer minimal support to overseas Chinese. The Guidance on China's Consular Protection and Assistance (2018) clearly states that Chinese consulates cannot offer any type of financial help to Chinese nationals abroad under any circumstances. This includes the loss of income and unemployment abroad. The consulate services have a function to inform the family in China of the overseas Chinese about their financial difficulties and can advise the family on how to transfer the funds needed.

\footnotetext{
${ }^{20}$ Ministry of Human Resources and Social Security (2009). 关于进一步做好在国内就业的华侨 参加社会保险有关工作的通知 [Notice on the overseas Chinese participation in social insurance for further employment]. http://www.gov.cn/zwgk/2009-10/30/content_1452856.htm. Accessed 4 March 2019.

${ }^{21}$ The National People's Congress (2010). 中华人民共和国社会保险法 [PRC's Social Insurance Law]. http://www.npc.gov.cn/npc/xinwen/2010-10/28/content_1602435.htm. Accessed 4 March 2019.

${ }^{22}$ The Consular Affairs Department of the Ministry of Foreign Affairs (2018). 中国领事保护和协 助指南 [Guidance on China's consular protection and assistance]. Beijing: Shijie Zhishi Press.
} 


\subsubsection{Health Care}

In the area of health care, the government institutions offer updates on health risks and healthcare provision on their website. ${ }^{23}$ In January 2018, the Ministry of Foreign Affairs introduced a new service on Weibo (Chinese version of Twitter) called Consular Voice (ling shi zhi shen 领事之声) where it publicizes consular updates and announces important information concerning overseas Chinese, including healthcare.

There is no national policy requiring Chinese consulates to assist overseas Chinese to access health insurance and benefits in China. In the PRC, participation in the medical insurance fund is arranged through the domestic employer in line with the 2011 Social Insurance Law. However, Chinese nationals residing abroad can maintain a form of health coverage in China if they continue to contribute to the National Health Insurance programme (yiliao baoxian 医疗保险). ${ }^{24}$ In case of medical emergency abroad, Chinese consulates do not provide medical services on their premises and do not provide any cash payments. Yet, they can supply a list of local medical institutions in the country of residence and assist the person to contact their family in China. The consulate's assistance in this area is limited to providing information about available services (legal support, translation services or medical care providers), but the cost of services and repatriation has to be covered by the person concerned or their family in China. ${ }^{25}$ If a Chinese national abroad develops a serious health issue and their family in China cannot make arrangements for their repatriation or arrange medical care, a Chinese consulate employee will assist family members with visa arrangements. However, all related medical, travel and other costs will have to be covered by the person concerned or their family in China. ${ }^{26}$

\subsubsection{Pensions}

According to the "Notice regarding benefits issues involving the retired and resigned personnel residing abroad", ${ }^{27}$ overseas Chinese retirees should be treated equally with retired nationals domestically.

\footnotetext{
${ }^{23} \mathrm{http}: / / \mathrm{cs} . \mathrm{mfa} . \mathrm{gov} . \mathrm{cn} /$. Accessed 6 April 2020.

${ }^{24}$ The National People's Congress (2010). 中华人民共和国社会保险法 [PRC's Social Insurance Law]. http://www.npc.gov.cn/npc/xinwen/2010-10/28/content_1602435.htm. Accessed 4 March 2019.

${ }^{25}$ See footnote 22 .

${ }^{26}$ See footnote 22 .

${ }^{27}$ Overseas Chinese Affairs Cadres' School of the Overseas Chinese Affairs Office of the State Council (2015). Q\&A on Policies and Regulations about Overseas Chinese Affairs. Beijing: Shijie Zhishi Press.
} 
The legal framework in the area of retirement is regulated by the PRC's Social Insurance Law (2011) and the "Implementation of the PRC's Social Insurance Law". Overseas Chinese can receive pensions abroad if they satisfy two conditions: 1) have participated in the national basic old-age insurance scheme and have contributed to it for at least 15 years, and 2) have reached the legal retirement age. To receive a pension, the person has to complete relevant procedures and obtain a pension account in China. The procedures for pension registrations vary across local social insurance agencies, and the claimant is advised to consult the local social insurance office in their residential area. Applicants can visit the website of the social insurance department where the pension is located or call the local 12,333 consular support line to find out about the specific policy. ${ }^{28}$

To receive pension funds abroad, retired overseas Chinese who satisfy the criteria for pension payments must present a life certificate entitled "Declaration Form for Exit and Retirement of Persons' Retirement", issued by Chinese embassies and consulates abroad, at least annually at the social insurance agencies responsible for pension payments. Overseas Chinese can also entrust relatives or others in China to receive pension payments.

As mentioned above, provisions for participation in the pension scheme by overseas Chinese vary from one province to another. In accordance with Article 24 of Zhejiang Province's "Regulations regarding protection of the rights and interests of overseas Chinese" (2018), if an overseas Chinese originating from the province contributes to the pension account for less than 10 years, they can contribute to it for another five years. If the payment is still insufficient for the minimum payment period set by the state after five years, it may be paid in one lump sum to the minimum payment period stipulated by the state. ${ }^{29}$

As opposed to Chinese retirees residing abroad, one emerging policy area concerns Chinese citizens working abroad. Since 2011, China has signed social security agreements with 12 countries, including Germany, South Korea, Denmark, Finland, Canada, Switzerland, the Netherlands, France, Spain, Luxembourg, Serbia, and Japan (China Business Law Journal 2018). The main purpose of the agreement is to ensure that international migrant workers do not pay double social security taxes. Without such agreements, Chinese employees working in Luxembourg, for example, would have had to contribute to Luxembourg's pension system. The same is true for Luxembourg employees working in China. The agreement exempts employees of one country from making social security contributions in the host country for a period of time (normally five years). Not every international employee is eligible, however. The agreements mainly apply to freelance individuals and

\footnotetext{
${ }^{28}$ Overseas Chinese Affairs Office (2018). 外籍华人能否在中国领养老金? [Can Chinese of foreign nationality receive pension from China abroad?]. http://www.gqb.gov.cn/ news/2018/0830/45316.shtml. Accessed 4 March 2019.

${ }^{29}$ Civil and Commercial Law Network (2018). 浙江省华侨权益保护条例全文 [Protection of overseas Chinese rights and interests in Zhejiang province]. http://m.liuxiaoer.com/fagui/116029_2. html. Accessed 4 March 2019.
} 
people working on an assignment, for instance, employees assigned by Chinese companies to work in Japan.

\subsubsection{Family-Related Benefits}

For nearly four decades, the PRC exercised strict population control policies that were relaxed in January 2016. There are no financial incentives for child birth or child benefits in China. Maternity leave and pay is arranged through a contractual relationship between a domestic employer and employee in accordance with State Council Order N619 on "Special provisions for labour protection for female employees". ${ }^{30}$ These provisions do not extend to overseas Chinese unless they work for a domestic employer operating overseas. Chinese nationals born abroad cannot obtain a birth certificate from Chinese authorities abroad. They receive a birth certificate issued by the country of residence that needs to be translated and certified at the Chinese consulate for receipt of a Chinese travel document that gives its holder the right to cross the border to the PRC as a Chinese national. ${ }^{31}$

\subsubsection{Economic Hardship}

Like in other areas of social protection of overseas Chinese, government institutions provide minimal support in case of economic hardship or destitution faced by a Chinese national abroad. The consulate restricts its role to informing the family in China and providing advice on how to transfer money for the overseas Chinese in economic hardship. ${ }^{32}$

In recent years, there have been concerted efforts by the Chinese government to mobilise overseas Chinese popular organisations to consolidate their own mutual support activities. In 2014, the OCAO in association with local overseas Chinese associations started the programme of setting up "Overseas Chinese Mutual Aid Centres" in cities around the world which hold a significant concentration of Chinese communities. In September 2015, the OCAO in Beijing announced the opening in the previous year of Overseas Chinese Service Centre in Houston (US). ${ }^{33}$

\footnotetext{
${ }^{30}$ The State Council (2012). 女职工劳动保护特别规定 [Special provisions on labour protection for female employees]. http://www.gov.cn/zwgk/2012-05/07/content_2131567.htm. Accessed 4 March 2019.

${ }^{31}$ Ministry of Public Security (2001). 公安部关于对出国人员所生子女落户问题的批复 [Reply of the office of public security on the settlement of Children born to overseas Chinese]. http:// www.chinalawedu.com/falvfagui/fg22598/54807.shtml. Accessed 4 March 2019.

${ }^{32}$ See footnote 22 .

${ }^{33}$ Overseas Chinese Service Centre (2018). 关于 ‘华助中心 [About overseas Chinese service centre]. http://chineseciviccenter.org/ocsc/index.html. Accessed 4 March 2019.
} 
The declared objective of the Centre was to help overseas Chinese to adapt to local life, including providing assistance with housing, employment, investment, residency, language training, and participation in local communities' cultural life (International Festivals, Thanksgiving, and so forth). In 2018, the State Council reported that 60 mutual aid centres operated in 40 countries around the world with the aim of providing legal assistance, volunteering opportunities, and advisory work on integration into the local society. ${ }^{34}$ Established and run exclusively by volunteers, the activities of the mutual aid centres are guided and supported by the OCAO which organises annual events in Beijing celebrating their work. Their efforts were acknowledged at the 2017 Global Overseas Chinese Awards ceremony. ${ }^{35}$ Providing care to Overseas Chinese who require help and assistance has become an important dimension of overseas Chinese work in recent years. Advertised as a non-profit service run by overseas Chinese volunteers with the aim of "care, help, and integration", the creation of the centres is guided by the assumption that all overseas Chinese continue to "love China" from abroad.

\subsection{Conclusions}

Overseas Chinese have historically played a significant role in China's national development and continue to occupy a central stage among government policy priorities. The State Council publishes annual updates on policy developments and achievements in the area of protection of the overseas Chinese rights and interests. The report presented at the 13th National People's Congress states that "the overseas Chinese have an irreplaceable important role in realizing the Chinese dream" . ${ }^{36}$ In recent years, "overseas Chinese affairs work" has developed through expanding policy infrastructure, encouraging China's diaspora to participate in national economy and trade, science and technology developments, and large-scale crisis response, yet has seen very limited developments in the area of day-to-day social protection of Chinese nationals abroad. The integration of the Overseas Chinese Affairs Office into the CPC structure through its merger with the United Front Work Department in March 2018, suggests a growing priority and significance of overseas Chinese policies for the party-state.

The Outline for the Development of the State's Overseas Chinese Affairs during the 13th Five-year plan (2016-2020) sets a direction for policy development. It is apparent from the document's emphasis on economy, science, technology, culture and education, that social protection of Chinese diaspora remains a non-priority as a sphere of government policies. The overseas Chinese work is aimed at co-opting

\footnotetext{
${ }^{34}$ See footnote 1.

${ }^{35}$ China News Network (2018)。2018助中心年会回䏬: 凝侨心侨力共享民族复兴梦 [2018 China Aid Centre Annual Meeting Review: Consolidation of Overseas Chinese and Sharing the Dream of National Rejuvenation]. http://www.chinaqw.com/huazhu/2018/01-14/175152.shtml. Accessed 3 March 2019.

${ }^{36}$ See footnote 1 .
} 
Chinese citizens abroad into economic, technological and image-making activities of the state rather than to responding to welfare needs of Chinese nationals residing abroad. This in large part mirrors China's limited domestic social welfare provisions which are mainly arranged through a contractual employer-employee relationship rather than guaranteed by the state.

Pension has been by far the most developed and debated area of social protection policies, with numerous queries from overseas Chinese retirees about how to receive pension funds from abroad and requests to simplify the paperwork submitted to Chinese consulates. In July 2018, at the press conference of the Ministry of Social Insurance, it was announced that the Chinese government is trialling a new internet video certification policy that might in the future replace the annual procedure of submitting the "Health Confirmation Form" in person to Chinese consulates for pension payments.

The lack of knowledge by overseas Chinese about social protection laws in the country of residence became a news headline in August 2017, when the China Overseas Network, the main portal for overseas Chinese affairs, published an article about a Chinese national living and working in Italy for over 20 years, who lost his low-income benefits pension after relocating to China, having violated the conditions for qualifying for the low-income benefits. Following this case, the Overseas China Network published information on basic pension regulations for a number of countries with a significant Chinese diaspora population. ${ }^{37}$

The growing number of Chinese nationals travelling, working and settling down overseas will likely lead to the expansion of China's activities in the area of social and welfare protection of its citizens abroad. Yet, for the time being, protection of citizens remains limited to the instances of emergency when China's national interests and global image are at stake.

Acknowledgements This chapter is part of the project "Migration and Transnational Social Protection in (Post)Crisis Europe (MiTSoPro)" that has received funding from the European Research Council (ERC) under the European Union's Horizon 2020 research and innovation programme (Grant agreement No. 680014). In addition to this chapter, readers can find a series of indicators comparing national social protection and diaspora policies across 40 countries on the following website: http://labos.ulg.ac.be/socialprotection/.

\section{References}

China Business Law Journal. (2018). China signs social security treaty with Japan. https://www. vantageasia.com/china-social-security-treaty-japan/. Accessed 15 May 2019.

Connolly, P. (2019). Protecting citizens overseas: The policy, the power and now the movie.... In J. Golley, L. Jaivin, P. J. Farrelly, \& S. Strange (Eds.), China story yearbook 2018: Power (pp. 319-325). Canberra: ANU Press.

\footnotetext{
${ }^{37}$ China Overseas Network. (2017). 海外侨胞请小心! 这样做, 你的养老金可能不保 [Overseas Chinese please be careful! Otherwise, your pension may not be guaranteed!]. http://world.people. com.cn/n1/2017/0810/c1002-29462973.html. Accessed 4 March 2019.
} 
Ding, S. (2015). Engaging diaspora via charm offensive and indigenised communication: An analysis of China's diaspora engagement policies in the Xi era. Politics, 35(3-4), 230-244.

Liu, H., \& Van Dongen, E. (2016). China's diaspora policies as a new mode of transnational governance. Journal of Contemporary China, 25(102), 805-821.

Pieke, F. N. (2012). Immigrant China. Modern China, 38(10), 40-77.

To, J. J. H. (2014). Qiaowu: Extra-territorial policies for the overseas Chinese. Leiden: Brill.

Wang, H., \& Kang, R. (2017). 世界华商发展报告 2017 [Report on Development Overseas Chinese Entrepreneurs 2017]. Beijing: The Chinese Overseas Publishing House.

Xiang, B. (2016). Emigration trends and policies in China: Movement of the wealthy and highly skilled. Washington, DC: Migration Policy Institute.

Zerba, S. (2014). China's Libya evacuation operation: A new diplomatic imperative-Overseas citizen protection. Journal of Contemporary China, 23(90), 1093-1112.

Zhao, H. (1994). 华侨华人经济与中国对外开放 [Overseas Chinese economy and China's opening-up]. 八桂侨史 [Bagui Journal of Overseas Chinese History], 1(21), 8-12.

Open Access This chapter is licensed under the terms of the Creative Commons Attribution 4.0 International License (http://creativecommons.org/licenses/by/4.0/), which permits use, sharing, adaptation, distribution and reproduction in any medium or format, as long as you give appropriate credit to the original author(s) and the source, provide a link to the Creative Commons license and indicate if changes were made.

The images or other third party material in this chapter are included in the chapter's Creative Commons license, unless indicated otherwise in a credit line to the material. If material is not included in the chapter's Creative Commons license and your intended use is not permitted by statutory regulation or exceeds the permitted use, you will need to obtain permission directly from the copyright holder.

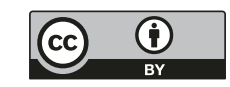

